\title{
CUMULATIVE AUTHOR INDEX
}

All authors published so far in the current volume are listed alphabetically with the issue and page numbers following the dash. A cumulative author and subject index covering each volume is published annually. An (E) after the page number indicates Erratum.

Allen, D. G. - (4) 311

Amon, T. T. - (2) 97

Anderson, T. M. - (2) 90

Anike, J. - (3) 242

Aytaç, Sevim Peri - (4) 325

Banerjee, Debasis - (1) 3

Barreda, Omar - (2) 119

Bergold, S. - (2) 143

Bian, X. - (3) 279

Blanton, J. R. - (2) 130, 164; (3) 233

Blanton, T. N. - (1) 50, 59, 66, 74;

(2) $130,164,189$; (3) 267, 282;

(4) $352,361,368,374,379,389$

Bloch, Eric D. - (2) 119

Boaz, Nicholas C. - (1) 50

Brewer, Greg A. - (4) 302

Brown-Shaklee, H. - (2) 97

Butler, Zachary R. - (4) 368, 379

Cai, J. - (4) 339

Chen, X. - (1) 3; (3) 279

Choi, Chul-Jin - (2) 196

Clarke, R. M. - (1) 21; (4) 311

Cockayne, E. - (3) 227

Coker, E. N. - (2) 90

Connors, David - (1) 3

Contreras-Torres, F. F. - (2) 110

Cook, Lawrence P. - (4) 302

Cui, Y. - (4) 339

Derbeshi, R. - (3) 242

Diulus, Samantha C. - (2) 189

Espinal, L. - (1) 13; (3) 216

Fathi, Mohammad Bagher - (3) 260

Fawcett, T. G. - (1) 74; (2) 130, 164

Gündoğdu, Gülsüm - (4) 325

Gates-Rector, S. - (1) 74; (2) 130, 164; (4) 352

Ghosh, S. - (2) 151

Giang Nguyen, Huong - (1) 13

Gindhart, A. M. - (1) 50, 59, 66; (2)

130, 164, 189; (3) 267, 282; (4)

361, 368, 374, 379, 389

Ginell, K. M. - (2) 184

Goetz-Neunhoeffer, F. - (2) 143

Goroff, Nancy - (1) 3
Green, N. - (2) 97

Griego, J. J. M. - (2) 90, 97

He, M. - (4) 339

Horn, C. - (2) 184

Horn, Jarod - (1) 13

Ichikawa, S. - (2) 159

Jansen, D. - (2) 143

Kabekkodu, S. N. - (2) 130, 164

Kaduk, J. A. - (1) 13, 35, 44, 50, 59, 66, 74; (2) 189; (3) 216, 242, 267,

282; (4) 331, 361, 368, 374, 379, 389

Karayel, Arzu - (4) 325

Kaynak, Filiz Betül - (4) 325

Kimpton, J. A. - (1) 21; (4) 311

King, N. - (3) 242

Krueger, Jordan A. - (1) 66

Kube, Christopher M. - (2) 103

Kurisaki, T. - (2) 159

Lan, Y. - (3) 242

Lan, Y. C. - (4) 331

Lapidus, Saul H. - (1) 13

Lawson, Matthew - (1) 13

Li, C. X. - (4) 345

Li, Lan - (1) 13

Li, M. - (4) 345

Lim, Jung Tae - (2) 196

Liu, G. Y. - (4) 331

Liu, S. M. - (4) 339

Liu, W. - (3) 242

Liu, W. F. - (4) 331

Lorzing, Gregory R. - (2) 119

Louër, Daniel - (3) 233

Matei, Lidia - (1) 44

Meng, Yongtao - (1) 13

Mukherjee, A. K. - (2) 151

Neubauer, J. - (2) 143

Nguyen, H. G. - (3) 216

Norberg, Nicholas - (2) 103

O’Connor, B. H. - (1) 21; (4) 311

Papoular, Robert J. - (3) 233

Parise, John B - (1) 3
Park, Jihoon - (2) 196

Plonka, Anna M. - (1) 3

Pramanik, S. - (2) 151

Reid, Joel W. - (1) 44

Rodriguez, M. A. - (2) 90, 97

Rost, M. - (2) 130, 164

Sakito, Y. - (2) 159

Sarguna, R. M. - (2) 124

Schreiner, J. - (2) 143

Shen, Y. - (4) 345

Si, Ping-Zhan - (2) 196

Siderius, D. W. - (3) 216

Siderius, Daniel - (4) 302

Song, B. - (4) 339

Sornadurai, D. - (2) 124

Sridharan, V. - (2) 124

Stacey, P. - (3) 251

Stirrup, K.-A. M. - (2) 90

Suib, Steven L. - (1) 13

Sun, Hui - (4) 297

Tao, H. L. - (4) 339

Toby, B. H. - (2) 184

Tozkoparan, Birsen - (4) 325

Vermeulen, Arnold C. - (2) 103

Volkmann, S. - (2) 143

Von Dreele, R. B. - (2) 184

Wang, Q. - (3) 279

Wang, S. - (3) 242; (4) 339

Wang, S. Y. - (4) 331

Webler, R. - (2) 143

Wheatley, Austin M. - (1) 35, 59; (3) 267

Windover, D. - (3) 242

Windover, D. A. - (4) 331

Woerner, William R. - (1) 3

Wong-Ng, W. - (3) 216, 242; (4) 331

Wong-Ng, Winnie - (1) 13; (4) 302

Wu, Di - (4) 297

Xu, H. D. - (4) 339

Yang, Y. Q. - (4) 331

Zhang, Z. H. - (4) 339

Zhong, K. - (1) 74 
1. Publication Title

Powder Diffraction

4. Issue Frequency

Quarterly March, June, Sept, December

. Complete Mailing Address of Known Office of Publication (Not printer) (Street, city, county, state, and ZIP+48)

Cambridge University Press

1 Liberty Plaza

New York, NY 10006

8. Complete Mailing Address of Headquarters or General Business Office of Publisher (Not printer)

Cambridge University Press

Edinburgh Building, Cambridge CB2 2RU, England
2. Publication Number

5. Number of Issues Published Annually

4

3. Filing Date

$10 / 1 / 2019$

6. Annual Subscription Price

$\$ 472.00$

Contact Person

Nina lammatteo

Telephone (Include area code)

2123375000

9. Full Names and Complete Mailing Addresses of Publisher, Editor, and Managing Editor (Do not leave blank)

Publisher (Name and complete mailing address)

Cambridge University Press

1 Liberty Plaza

New York, NY 10006

Editor (Name and complete mailing address)

Camden Hubbard, International Centre for Diffraction Data, 12 Campus Blvd, Newtown Square, PA 19073-3273 USA

Managing Editor (Name and complete mailing address)

10. Owner (Do not leave blank. If the publication is owned by a corporation, give the name and address of the corporation immediately followed by the names and addresses of all stockholders owning or holding 1 percent or more of the total amount of stock. If not owned by a corporation, give the names and addresses of the individual owners. If owned by a partnership or other unincorporated firm, give its name and address as well as those of each individual owner. If the publication is published by a nonprofit organization, give its name and address.)

\begin{tabular}{l|l}
\hline Full Name & Complete Mailing Address \\
\hline The International Centre for Diffraction Data & 12 Campus Blvd. \\
\hline & Newtown Square, PA 19073-3273 \\
\hline & USA \\
\hline & \\
\hline
\end{tabular}

11. Known Bondholders, Mortgagees, and Other Security Holders Owning or Holding 1 Percent or More of Total Amount of Bonds, Mortgages, or Other Securities. If none, check box 区 None

\begin{tabular}{l|l}
\hline Full Name & Complete Mailing Address \\
\hline
\end{tabular}

12. Tax Status (For completion by nonprofit organizations authorized to mail at nonprofit rates) (Check one)

The purpose, function, and nonprofit status of this organization and the exempt status for federal income tax purposes:

$\square$ Has Not Changed During Preceding 12 Months

$\square$ Has Changed During Preceding 12 Months (Publisher must submit explanation of change with this statement)

PS Form 3526, July 2014 [Page 1 of 4 (see instructions page 4)] PSN: 7530-01-000-9931

PRIVACY NOTICE: See our privacy policy on www.usps.com. 


\begin{tabular}{|c|c|c|c|c|}
\hline \multirow{2}{*}{\multicolumn{3}{|c|}{$\begin{array}{l}\text { 13. Publication Title } \\
\text { Powder Diffraction } \\
\text { 15. Extent and Nature of Circulation }\end{array}$}} & \multicolumn{2}{|c|}{$\begin{array}{l}\text { 14. Issue Date for Circulation Data Below } \\
\text { JUNE } 2019\end{array}$} \\
\hline & & & \multirow{2}{*}{$\begin{array}{l}\text { Average No. Copies } \\
\text { Each Issue During } \\
\text { Preceding } 12 \text { Months }\end{array}$} & $\begin{array}{l}\text { No. Copies of Single } \\
\text { Issue Published } \\
\text { Nearest to Filing Date }\end{array}$ \\
\hline \multicolumn{3}{|c|}{ a. Total Number of Copies (Net press run) } & & 250 \\
\hline \multirow{4}{*}{$\begin{array}{l}\text { b. Paid } \\
\text { Circulation } \\
\text { (By Mail } \\
\text { and } \\
\text { Outside } \\
\text { the Mail) }\end{array}$} & (1) & $\begin{array}{l}\text { Mailed Outside-County Paid Subscriptions Stated on PS Form } 3541 \text { (Include paid } \\
\text { distribution above nominal rate, advertiser's proof copies, and exchange copies) }\end{array}$ & 40 & 34 \\
\hline & (2) & $\begin{array}{l}\text { Mailed In-County Paid Subscriptions Stated on PS Form } 3541 \text { (Include paid } \\
\text { distribution above nominal rate, advertiser's proof copies, and exchange copies) }\end{array}$ & 0 & 0 \\
\hline & (3) & $\begin{array}{l}\text { Paid Distribution Outside the Mails Including Sales Through Dealers and Carriers, } \\
\text { Street Vendors, Counter Sales, and Other Paid Distribution Outside USPS }{ }^{\circledR}\end{array}$ & 135 & 120 \\
\hline & (4) & $\begin{array}{l}\text { Paid Distribution by Other Classes of Mail Through the USPS } \\
\left.\text { (e.g., First-Class Mail }{ }^{\otimes}\right)\end{array}$ & 0 & 0 \\
\hline \multicolumn{3}{|c|}{ c. Total Paid Distribution [Sum of 15b (1), (2), (3), and (4)] } & 175 & 154 \\
\hline \multirow{4}{*}{$\begin{array}{l}\text { d. Free or } \\
\text { Nominal } \\
\text { Rate } \\
\text { Distribution } \\
\text { (By Mail } \\
\text { and } \\
\text { Outside } \\
\text { the Mail) }\end{array}$} & (1) & Free or Nominal Rate Outside-County Copies included on PS Form 3541 & 0 & 0 \\
\hline & (2) & Free or Nominal Rate In-County Copies Included on PS Form 3541 & 0 & 0 \\
\hline & (3) & $\begin{array}{l}\text { Free or Nominal Rate Copies Mailed at Other Classes Through the USPS } \\
\text { (e.g., First-Class Mail) }\end{array}$ & 0 & 0 \\
\hline & (4) & Free or Nominal Rate Distribution Outside the Mail (Carriers or other means) & 2 & 2 \\
\hline \multicolumn{3}{|c|}{ e. Total Free or Nominal Rate Distribution (Sum of 15d (1), (2), (3) and (4)) } & 2 & 2 \\
\hline \multicolumn{3}{|c|}{ f. Total Distribution (Sum of $15 \mathrm{c}$ and $15 \mathrm{e}$ ) } & 177 & 156 \\
\hline \multicolumn{3}{|c|}{ g. Copies not Distributed (See Instructions to Publishers \#4 (page \#3)) } & 171 & 94 \\
\hline \multicolumn{3}{|c|}{ h. Total (Sum of $15 f$ and $g$ ) } & 348 & 250 \\
\hline \multicolumn{3}{|c|}{$\begin{array}{l}\text { i. Percent Paid } \\
\text { (15c divided by } 15 f \text { times } 100)\end{array}$} & $98.87 \%$ & $98.72 \%$ \\
\hline
\end{tabular}

* If you are claiming electronic copies, go to line 16 on page 3. If you are not claiming electronic copies, skip to line 17 on page 3. 
a. Paid Electronic Copies

b. Total Paid Print Copies (Line 15c) + Paid Electronic Copies (Line 16a)

c. Total Print Distribution (Line 15f) + Paid Electronic Copies (Line 16a)

d. Percent Paid (Both Print \& Electronic Copies) ( $16 \mathrm{~b}$ divided by $16 \mathrm{c} \times 100$ )

I certify that $50 \%$ of all my distributed copies (electronic and print) are paid above a nominal price.

17. Publication of Statement of Ownership

If the publication is a general publication, publication of this statement is required. Will be printed

in the Deceurter issue of this publication.

18. Signature and Title of Editor, Publisher, Business Manager, or Owner
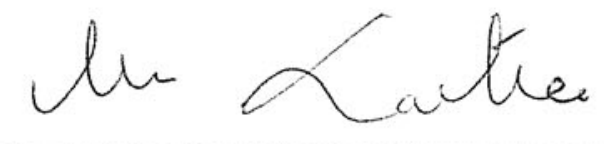

\section{Signalure and Tille of Editor, Publisher, Business Manager, or Owner}

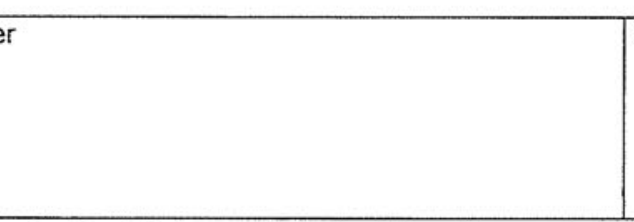

Date
$10 / 1 / 2019$

I certify that all information furnished on this form is true and complete. I understand that anyone who furnishes false or misleading information on this form or who omits material or information requested on the form may be subject to criminal sanctions (including fines and imprisonment) and/or civil sanctions (including civil penalties). 
I NTERNATIONAL CENTRE FOR DIFFRACTION DATA

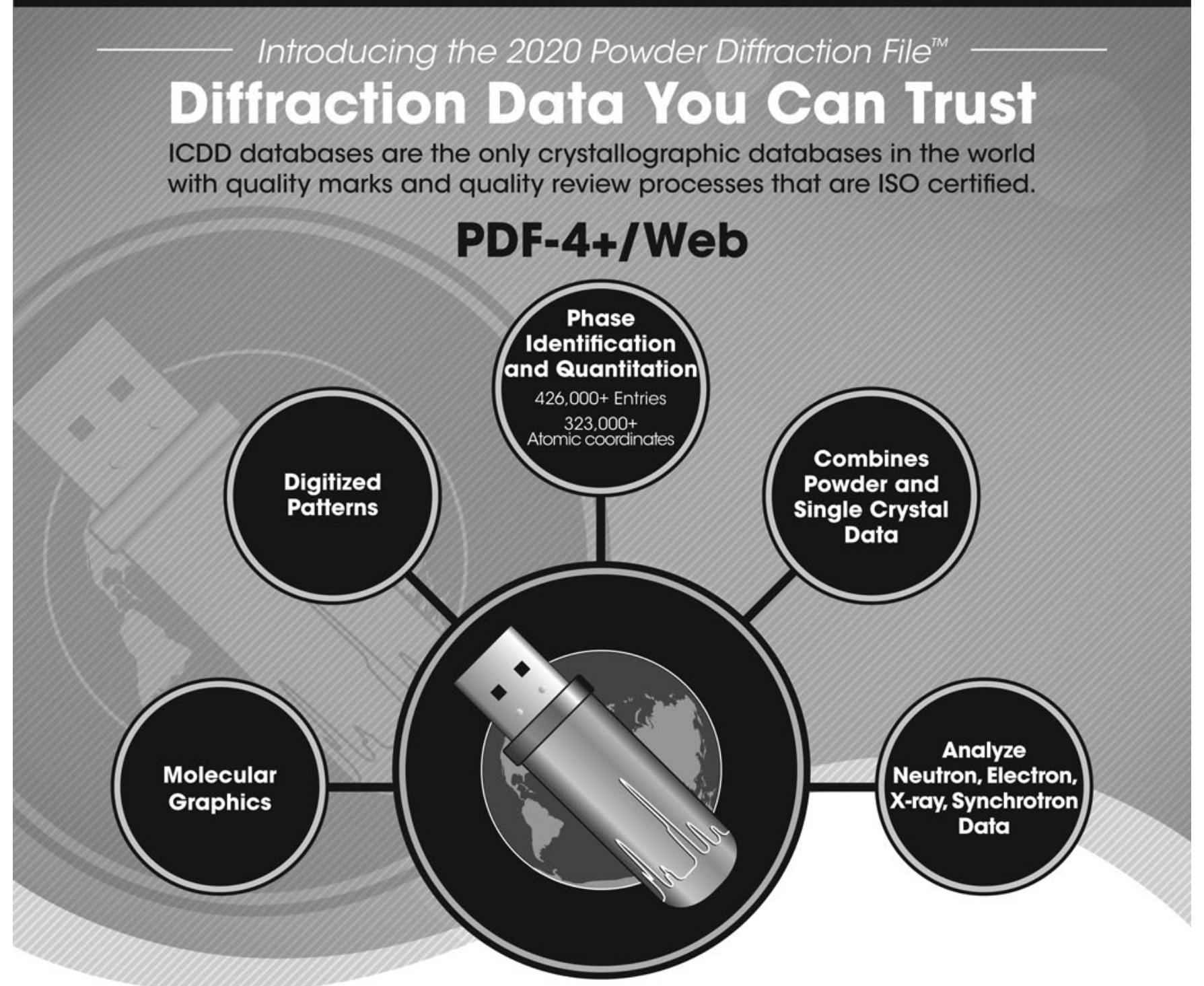

\section{Standardized Data \\ More Coverage}

All Data Sets Evaluated For Quality

Reviewed, Edited and Corrected Prior To Publication

Targeted For Material Identification and Characterization 
I NTERNATIONAL CENTRE FOR DIFFRACTION DATA

\section{Introducing the 2020 Powder Diffraction File Diffiraction Datio You Can Trust}

ICDD databases are the only crystallographic databases in the world with quality marks and quality review processes that are ISO certified.

\section{PDF-4/Axiom}

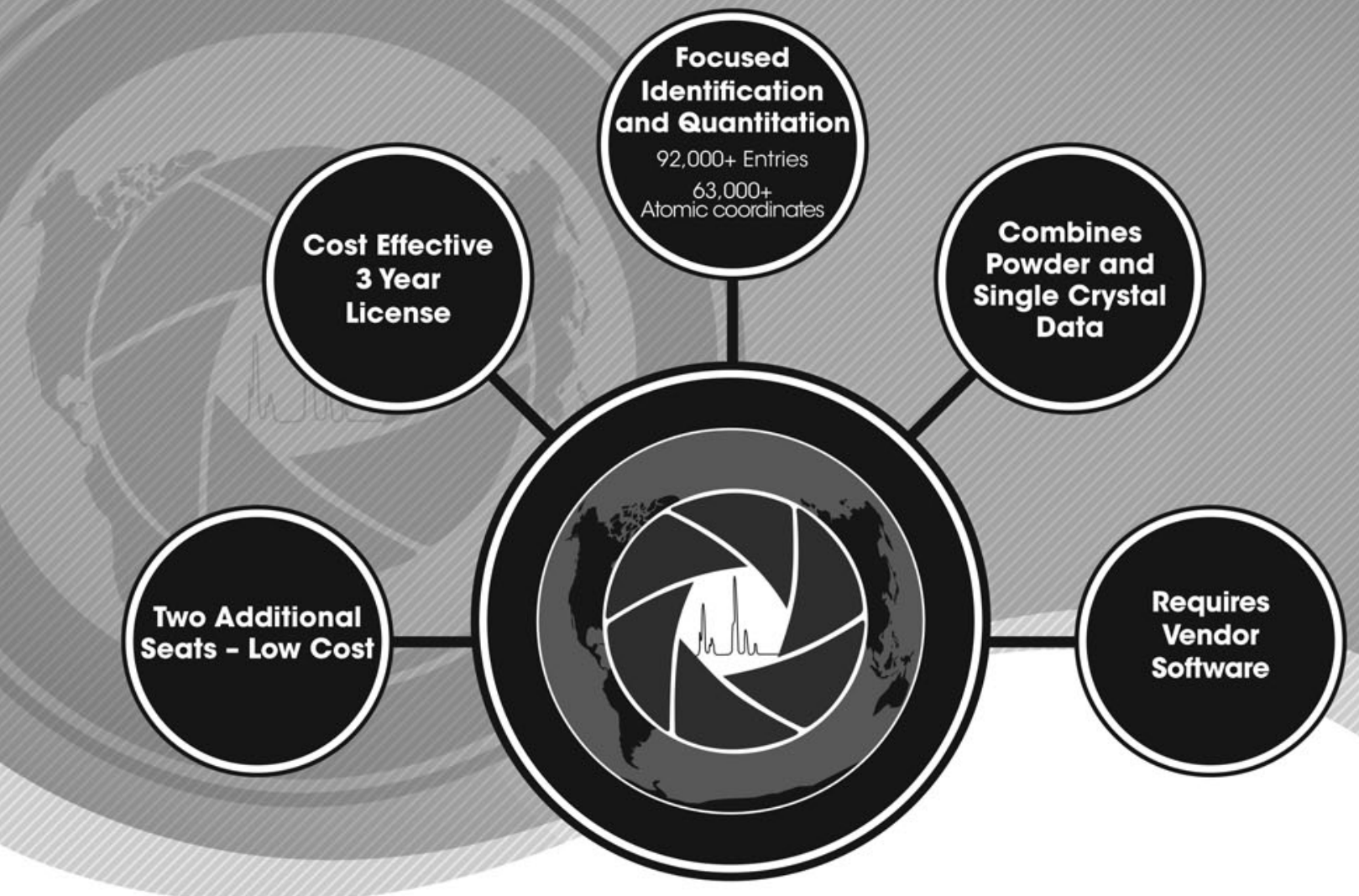

Standardized Data

All Data Sets Evaluated For Quality

Reviewed, Edited and Corrected Prior To Publication

Targeted For Material Identification and Characterization

(-) $($ (0) (in) (-)

www.icdd.com | marketing@icdd.com

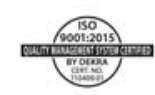

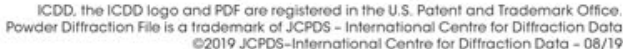




\section{NTER N ATIONAL CENTRE FOR DIFFRACTION DATA LET OUR IEAN OF EXPERIS HIEL YOU IAKE YOUR SKILLS TO THE NEXT LEVEH}

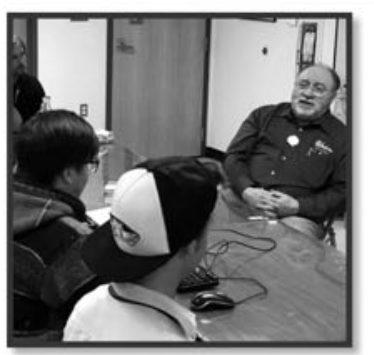

\section{Practical X-ray Fluorescence Clinic:}

27 April - 1 May 2020

From theory to hands-on exercises, this course offers techniques and skills to improve lab performance. Discover the latest in cutting-edge instruments such as TXRF, hand-held devices, energy dispersive and wavelength dispersive spectrometers through live demonstrations.

The XRF course covers the basics of X-ray spectra; instrumentation design; methods of qualitative and quantitative analysis; specimen preparation and applications for both wavelength and energy dispersive spectrometry. The course emphasizes quantitative methods, use of automated X-ray spectrometers, review of mathematical matrix correction procedures, and new developments in XRF.

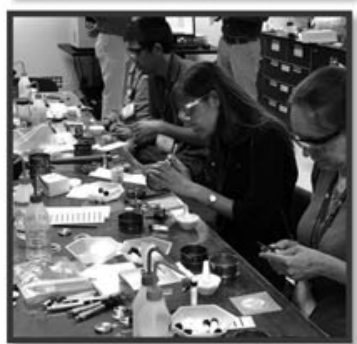

\section{Fundamentals of X-ray Powder Diffraction Clinic:}

\section{1 - 5 June 2020}

For the novice with some XRD knowledge or for the experienced with an interest in the theory behind XRD, this clinic offers a strong base for increased lab performance.

The clinic covers instrumentation, specimen preparation, data acquisition and qualitative phase analysis through live demonstrations. It also covers hands-on use of personal computers for demonstration of the latest software including data mining with the Powder Diffraction File (PDF) and use of the powder diffractometer: optical arrangement, factors affecting instrumentation profile width, choice and function of divergence slit, calibration and alignment, detectors, and X-ray optics.

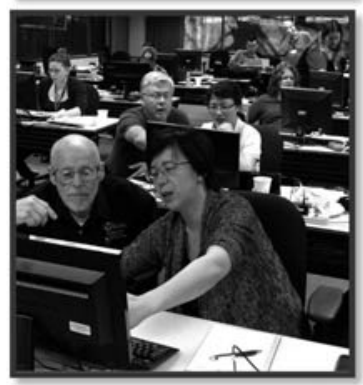

\section{Advanced Methods in X-ray Powder Diffraction Clinic:}

8 - 12 June 2020

For the experienced XRD scientist, this session offers enhanced analysis skills through intense problem solving. as well as an introduction to the Rietveld Method. The course emphasizes computer-based methods of data interpretation, both for qualitative and quantitative phase analysis.

The advanced course covers a wide range of topics including systematic errors, factors affecting intensities of diffraction peaks; data reduction algorithms; phase identification; advanced data mining with the PDF and its application in search/match; powder pattern indexing methods; structure solution methods; quantitative phase analysis using both reference intensity ration (RIR) and Rietveld Method.

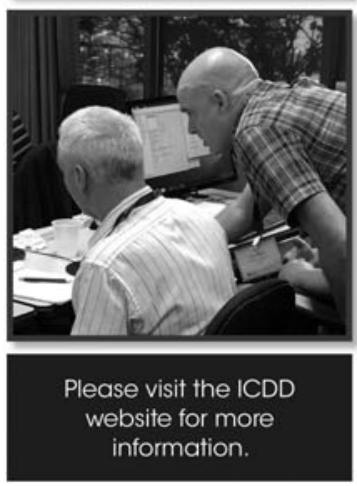

\section{Rietveld Refinement \& Indexing Clinic:}

28 September - 2 October 2020

Powder pattern indexing and Rietveld structural refinement techniques are complementary and are often used to completely describe the structure of a material. Successful indexing of a powder pattern is considered strong evidence for phase purity. Indexing is considered a prelude to determining the crystal structure, and permits phase identification by lattice matching techniques. This clinic introduces the theory and formalisms of various indexing methods and structural refinement techniques along with quantitative analysis. One unique aspect of this clinic is the extensive use of computer laboratory problem solving and exercises that teach method development in a hands-on environment.

\section{Register today at WWW.ICDD.COM}

Please note: A minimum of 10 registrants per course is required, otherwise the course will be cancelled and your registration fee will be refunded. You will be notified of a course cancellation no later than two weeks prior to the start of the course.

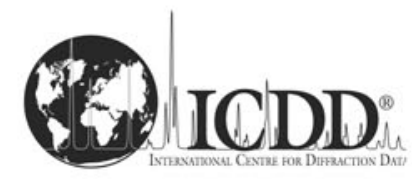

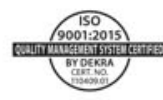

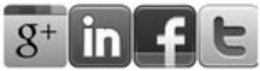

\section{For More Information Contact:}

Eileen Jennings, Education Coordinator

Tel: 610.325.9814 Fax: 610.325.9823

Email: clinics@icdd.com

\section{Location}

ICDD Headquarters, 12 Campus Boulevard Newtown Square, Pennsylvania 19073-3273 USA 


\section{NTERNATIONAL CENTRE FOR DIFFRACTION DATA}

\section{Diffiraction Daite You Can Trust}

ICDD databases are the only crystallographic databases in the world with quality marks and quality review processes that are ISO certified.

\section{PDF-4/Minerals}

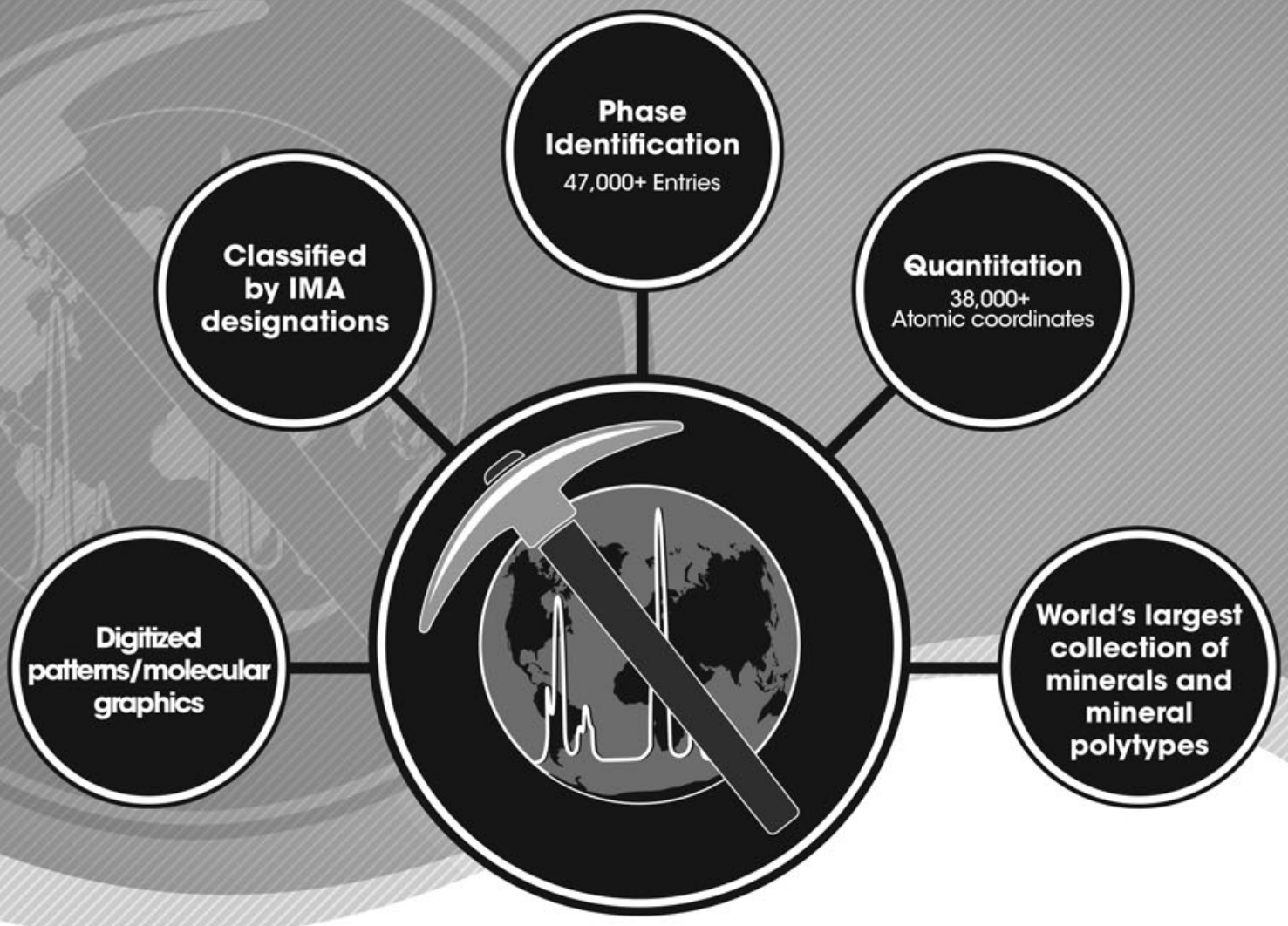

Standardized Data

More Coverage

All Data Sets Evaluated For Quality

Reviewed, Edited and Corrected Prior To Publication

Targeted For Material Identification and Characterization

(-) (ㅇ) in (-) www.icdd.com | marketing@icdd.com

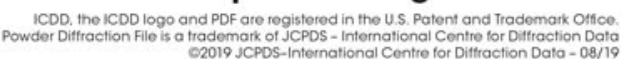




\section{Better \\ TOGE丁HER}

SAVE $15 \%$ on our New Bundles

PDF-4+ and JADE Pro 2020

PDF-4/Organics and JADE Pro 2020

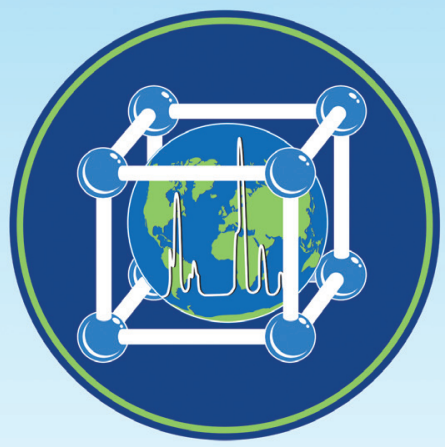

Phase Identification \& Quantitation

PDF-4+ features more data, higher quality, more content standardized data, and editorial evaluated data reviewed, edited and corrected prior to publication

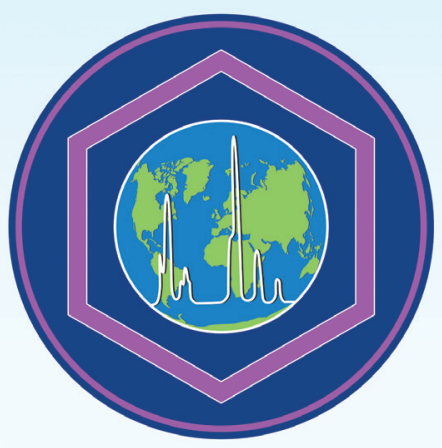

\section{Solve Difficult Problems, Get Better Results}

PDF-4/Organics database is a highly targeted collection, with special focus on materials used in commercial and regulatory fields. It provides the best of both worlds by including single crystal and powder diffraction data together in a single, edited, and standardized database.

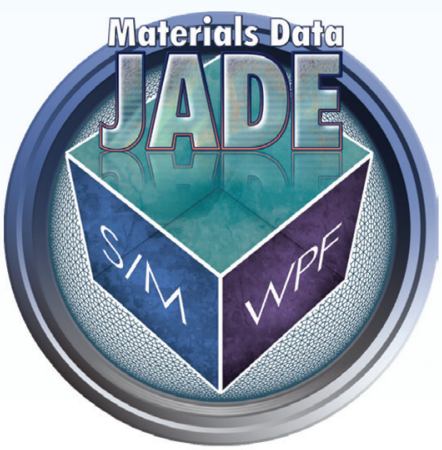

Scientists Trust Materials Data

JADE Pro Is a powerful, all-purpose powder XRD pattern viewer, processing and analysis program with emphasis on quantification and phase ID.

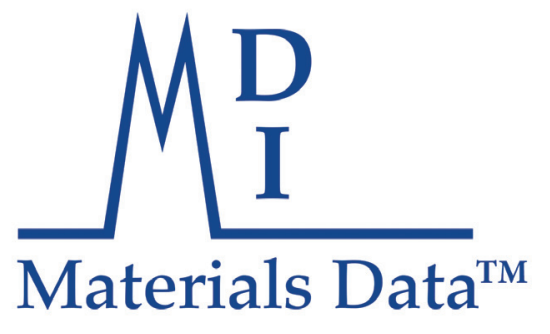




\section{HIGH-RESOLUTION DIFFRACTION}

Customizable high-resolution diffractometers for

characterizing thin films and single crystal materials.

·X-RAY REFLECTIVITY (XRR) · ROCKING CURVES

-RECIPROCAL SPACE MAPPING
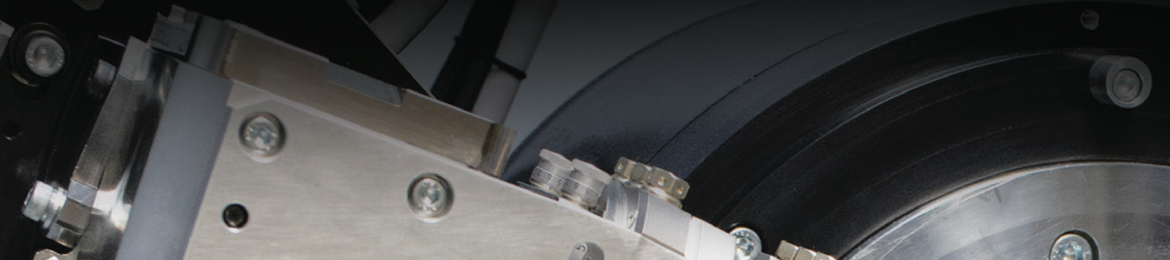

(2)

.

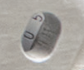

(2)

(9)

(19)
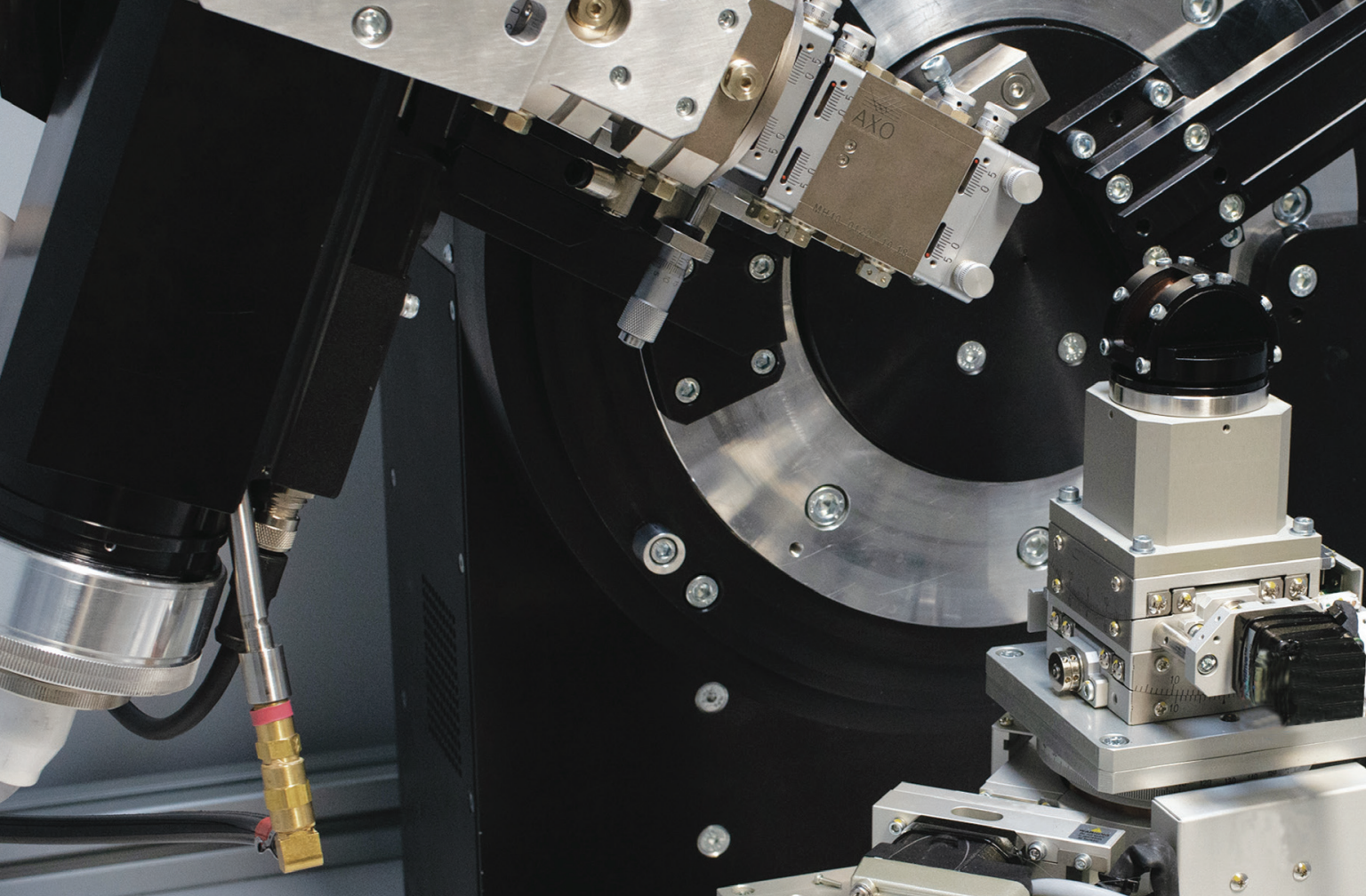

()

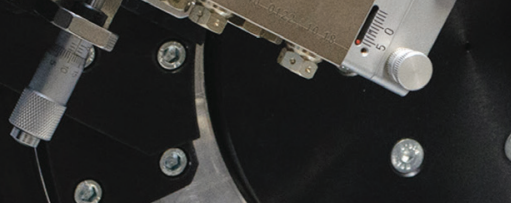

0

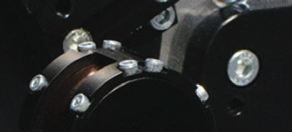

(2)

8

Q $v^{-\infty}-1$

Q

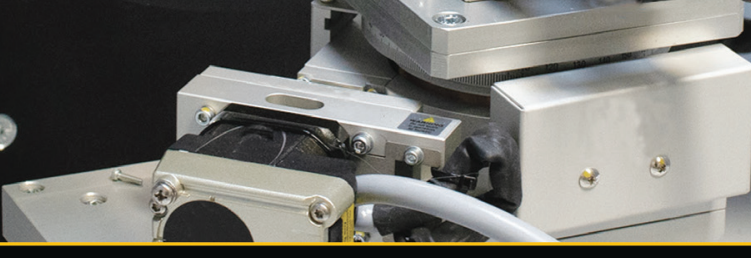

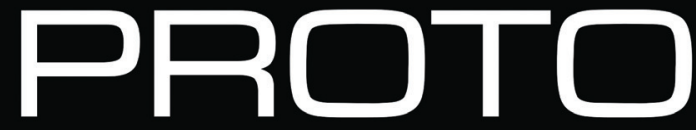

x-ray diffraction systems \& services
For more information and to download our product catalog.

1-734-946-0974 powder@protoxrd.com 